\title{
Elevation of Village Settlements by Municipalities in the River Basin of Crna Reka and Their Importance for Development of Tourism in the Republic of Macedonia*
}

\author{
Cane Koteski \\ University Goce Delchev, Stip, Republic of Macedonia
}

\begin{abstract}
The drainage area of Crna Reka is a spatial area that extends into two states in the southwestern part of the Republic of Macedonia. The boundaries of Macedonia and the northern part of the Republic of Greece are naturally clearly defined. The drainage area of Crna Reka in the Republic of Macedonia extends between 4051'56"and 41 $366^{\prime} 20^{\prime \prime}$ s.š.i $20^{\circ} 56^{\prime} 45^{\prime \prime}$ and $22^{\circ} 4^{\prime} 58^{\prime \prime}$. The total length of Crna Reka is $207 \mathrm{~km}^{2}$, with a total area of the catchment area (in both countries) of $5,774.99 \mathrm{~km}^{2}$, of which the Republic of Macedonia belongs the largest part of 4,869.72 $\mathrm{km}^{2}$, while the Republic of Greece belongs $905,27 \mathrm{~km}^{2}$. The research paper presents 335 village settlements located in 13 municipalities in the Crna Reka Basin in the Republic of Macedonia. Macedonia and another 50 settlements settlement plus the city of Lerin are located in the neighboring Republic of Greece. Let us see how spatial and which rural settlements are located in the Crna River Basin in both countries. The villages will be represented by municipalities according to their main characteristics, municipal belonging, and altitude.
\end{abstract}

Keywords: river basin, village settlements, altitude

\section{Introduction}

The rural settlements differ from the cities according to their physiognomy, or type, size, and population, have different construction and urban design, after the occupation of the population where the main activity is agriculture and the modest beginnings for the development of rural tourism in the villages of infrastructure facilities. In the Crna River Basin, there are 335 villages and three towns that belong to 13 municipalities in the Republic of Macedonia and 50 villages and plus the city of Lerin in the neighboring Republic of Greece. To see the spatial distribution of rural settlements in the Crna Reka Basin will be presented the villages according to their municipal belonging and altitude (Koteski, 2011, pp. 178-194).

\section{Elevation of Village Settlements by Municipalities in the Crna Reka River Basin in the Republic of Macedonia}

The height distribution of rural settlements is a very important element in the study of settlements,

\footnotetext{
*Acknowledgements: This scientific paper was published as part of the research project "Possibilities and Perspectives for the Development of Tourism in the Black River Basin” funded by Goce Delcev University, Stip, Macedonia (Contract No. 0206-151/16, 0201-545/9 and 0307-98/77, from 01.11.2017) and the Senate Decision No. 0201-922/30 of 21 November 2018.

Cane Koteski, Ph.D., associate professor, Faculty of Tourism and Business Logistics, University Goce Delcev, Stip, Republic of Macedonia.
} 
especially for road infrastructure, the size of arable land, urbanization of rural settlements, migrations, and other characteristics. To see the distribution of the villages according to the altitude of the Black River Basin in the Republic of Macedonia, their categorization was done in the villages from: 0-600 m, 600-700 m, 700-900 m, and above $900 \mathrm{~m}$ elevation (Koteski, 2011, pp. 203-209). Field research for 50 villages in the neighboring Republic of Greece is conducted due to the bad political relations between the Republic of Macedonia and the Republic of Greece.

Table 1

A Review of the Villages That Are Located From 0-600 m, 600-700 m, 700-900 m, and above $900 \mathrm{~m}$, in the River Basin of Crna Reka in Municipalities and Settlements in the Republic of Macedonia

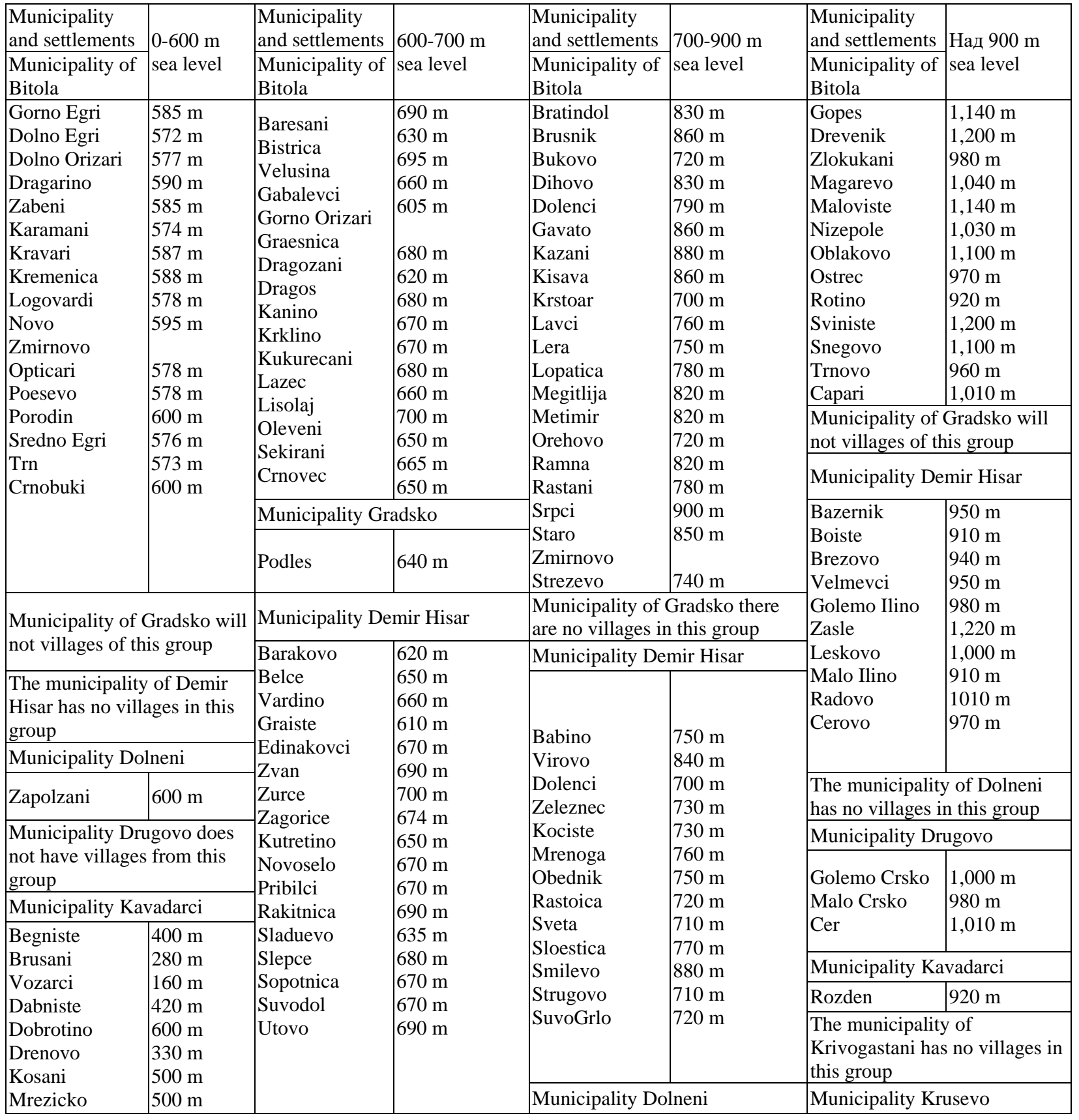




\begin{tabular}{|c|c|c|c|c|c|c|c|}
\hline \multirow{3}{*}{\begin{tabular}{|l} 
Raec \\
Resava \\
Faris \\
Sivec
\end{tabular}} & \multirow{3}{*}{$\begin{array}{l}300 \mathrm{~m} \\
330 \mathrm{~m} \\
415 \mathrm{~m} \\
180 \mathrm{~m}\end{array}$} & \multicolumn{2}{|c|}{ Municipality Dolneni } & \multirow{6}{*}{$\begin{array}{l}\text { Gorno Selo } \\
\text { Gostirazni } \\
\text { Drenovci } \\
\text { Zrze } \\
\text { Lazani } \\
\text { MaloMramorani } \\
\text { Margari } \\
\text { Strovija }\end{array}$} & \multirow{6}{*}{$\begin{array}{l}750 \mathrm{~m} \\
740 \mathrm{~m} \\
770 \mathrm{~m} \\
720 \mathrm{~m} \\
780 \mathrm{~m} \\
715 \mathrm{~m} \\
760 \mathrm{~m} \\
720 \mathrm{~m}\end{array}$} & \multirow{2}{*}{$\begin{array}{l}\text { Birino } \\
\text { PustaReka } \\
\text { Selce }\end{array}$} & \multirow{2}{*}{$\begin{array}{l}970 \mathrm{~m} \\
940 \mathrm{~m} \\
920 \mathrm{~m}\end{array}$} \\
\hline & & \multirow{17}{*}{$\begin{array}{l}\text { Belopole } \\
\text { Brailovo } \\
\text { Vrance } \\
\text { Dabjani } \\
\text { Debreste } \\
\text { Desovo } \\
\text { Dolgaec } \\
\text { Dolneni } \\
\text { Dupjacani } \\
\text { Zabjani } \\
\text { Zitose } \\
\text { Zabrcani } \\
\text { Kostinci } \\
\text { Kosino } \\
\text { Kutlesevo } \\
\text { Lokveni } \\
\text { Nebregovo } \\
\text { Novoselani } \\
- \text { Pestalevo } \\
\text { Rilevo } \\
\text { Ropotovo } \\
\text { Sarandinovo } \\
\text { Sekirci } \\
\text { Senokos } \\
\text { Slepce } \\
\text { Slivje } \\
\text { Sredorek } \\
\text { Crniliste }\end{array}$} & \multirow{17}{*}{$\begin{array}{l}610 \mathrm{~m} \\
660 \mathrm{~m} \\
603 \mathrm{~m} \\
605 \mathrm{~m} \\
680 \mathrm{~m} \\
680 \mathrm{~m} \\
700 \mathrm{~m} \\
622 \mathrm{~m} \\
660 \mathrm{~m} \\
630 \mathrm{~m} \\
630 \mathrm{~m} \\
660 \mathrm{~m} \\
620 \mathrm{~m} \\
690 \mathrm{~m} \\
660 \mathrm{~m} \\
625 \mathrm{~m} \\
700 \mathrm{~m} \\
620 \mathrm{~m} \\
610 \mathrm{~m} \\
660 \mathrm{~m} \\
610 \mathrm{~m} \\
610 \mathrm{~m} \\
620 \mathrm{~m} \\
623 \mathrm{~m} \\
700 \mathrm{~m} \\
625 \mathrm{~m} \\
602 \mathrm{~m} \\
662 \mathrm{~m}\end{array}$} & & & & \\
\hline & & & & & & $\begin{array}{l}\text { Municipali } \\
\text { villages in }\end{array}$ & $\begin{array}{l}\text { Mogila has no } \\
\text { roup }\end{array}$ \\
\hline \multirow{2}{*}{\multicolumn{2}{|c|}{ Municipality Krivogastani }} & & & & & Municipali & jvaci \\
\hline & & & & & & Grumazi & $1,090 \mathrm{~m}$ \\
\hline \multirow{4}{*}{\begin{tabular}{|l} 
Borotino \\
Vrbjani \\
Kruseani \\
Obrsani \\
Pasino Ruvci \\
Slavej \\
\end{tabular}} & \multirow{4}{*}{$\begin{array}{l}590 \mathrm{~m} \\
548 \mathrm{~m} \\
597 \mathrm{~m} \\
589 \mathrm{~m} \\
585 \mathrm{~m} \\
600 \mathrm{~m} \\
\end{array}$} & & & & & Iveni & $940 \mathrm{~m}$ \\
\hline & & & & \multicolumn{2}{|c|}{\begin{tabular}{|l} 
Municipality Drugovo do \\
have villages from this g
\end{tabular}} & $\begin{array}{l}\text { Polog } \\
\text { Sovic }\end{array}$ & $\begin{array}{l}940 \mathrm{~m} \\
1,080 \mathrm{~m}\end{array}$ \\
\hline & & & & \multicolumn{2}{|c|}{ Municipality Kavadarci } & \multicolumn{2}{|c|}{ Municipality Prilep } \\
\hline & & & & \multirow{2}{*}{\begin{tabular}{|l|} 
Bojanciste \\
Galiste \\
Klinovo \\
Kumanicevo \\
Majden \\
\end{tabular}} & \multirow{2}{*}{$\begin{array}{l}900 \mathrm{~m} \\
740 \mathrm{~m} \\
770 \mathrm{~m} \\
900 \mathrm{~m} \\
780 \mathrm{~m}\end{array}$} & \multirow{2}{*}{\begin{tabular}{|l} 
Zivovo \\
Krstec \\
Pletvar \\
Polciste \\
Prisad
\end{tabular}} & \multirow[b]{2}{*}{$\begin{array}{l}920 \mathrm{~m} \\
1,080 \mathrm{~m} \\
990 \mathrm{~m} \\
910 \mathrm{~m} \\
940 \mathrm{~m}\end{array}$} \\
\hline \multirow{2}{*}{\multicolumn{2}{|c|}{$\begin{array}{l}\text { The municipality of Krusevo } \\
\text { has no villages in this group }\end{array}$}} & & & & & & \\
\hline & & & & \multicolumn{2}{|c|}{$\begin{array}{l}\text { ОпштинаКривогаштани } \\
\text { немаселаодоваагрупа }\end{array}$} & \multirow{2}{*}{\multicolumn{2}{|c|}{$\begin{array}{l}\text { The municipality of Rosoman } \\
\text { has no villages in this group } \\
\text { Municipality of Caska has no } \\
\text { villages in this group } \\
\end{array}$}} \\
\hline \multirow{2}{*}{\multicolumn{2}{|c|}{ Municipality Mogila }} & & & \multicolumn{2}{|c|}{ Municipality Krusevo } & & \\
\hline & & & & \multirow[b]{2}{*}{\begin{tabular}{|l|} 
Belusino \\
Gorno \\
Divjaci \\
Dolno \\
Divjaci \\
Jakrenovo \\
Norovo \\
Ostrilci \\
\end{tabular}} & & & \\
\hline \multirow{4}{*}{$\begin{array}{l}\text { Budakovo } \\
\text { Vasarejca } \\
\text { Gorna Carlija } \\
\text { Dedebalci } \\
\text { Dobrusevo } \\
\text { Dolna Carlija } \\
\text { Loznani } \\
\text { Mogila } \\
\text { Nospal } \\
\text { Radobor } \\
\text { Trap } \\
\end{array}$} & \multirow{4}{*}{\begin{tabular}{|l}
$525 \mathrm{~m}$ \\
$584 \mathrm{~m}$ \\
$583 \mathrm{~m}$ \\
$592 \mathrm{~m}$ \\
$594 \mathrm{~m}$ \\
$582 \mathrm{~m}$ \\
$600 \mathrm{~m}$ \\
$582 \mathrm{~m}$ \\
$588 \mathrm{~m}$ \\
$531 \mathrm{~m}$ \\
$573 \mathrm{~m}$
\end{tabular}} & & & & $\begin{array}{l}800 \mathrm{~m} \\
860 \mathrm{~m} \\
730 \mathrm{~m} \\
785 \mathrm{~m} \\
860 \mathrm{~m}\end{array}$ & & \\
\hline & & & & \multicolumn{2}{|c|}{ Municipality Mogila } & & \\
\hline & & & & Mojno & $710 \mathrm{~m}$ & & \\
\hline & & & & \multicolumn{2}{|c|}{ Municipality Novaci } & & \\
\hline \multicolumn{2}{|c|}{ Municipality Novaci } & & & \multirow{6}{*}{\begin{tabular}{|l} 
Armatus \\
Brnik \\
Brod \\
Budimirci \\
Gnilez \\
Gradesnica \\
Grunista \\
Dolno \\
Orehovo \\
Zivojno \\
Meglenci \\
Orle \\
Paralovo \\
Petalino \\
Staravina \\
Tepavci
\end{tabular}} & $840 \mathrm{~m}$ & & \\
\hline $\begin{array}{l}\text { Biljanik } \\
\text { Gneotino } \\
\text { GornoAglarci }\end{array}$ & $\begin{array}{l}580 \mathrm{~m} \\
577 \mathrm{~m} \\
590 \mathrm{~m}\end{array}$ & $\begin{array}{l}\text { Municipality } \\
\text { not have villa } \\
\text { group of villa } \\
\end{array}$ & $\begin{array}{l}\text { Drugovo does } \\
\text { s from this } \\
\text { s }\end{array}$ & & $\begin{array}{l}740 \mathrm{~m} \\
740 \mathrm{~m} \\
800 \mathrm{~m} \\
840 \mathrm{~m}\end{array}$ & & \\
\hline Dalbegovci & $592 \mathrm{~m}$ & Municipality & avadarci & & & & \\
\hline $\begin{array}{l}\text { Dobroveni } \\
\text { Dobromiri } \\
\text { DolnoAglarci } \\
\text { Novaci } \\
\text { Ribarci } \\
\text { Skocivir }\end{array}$ & $\begin{array}{l}580 \mathrm{~m} \\
575 \mathrm{~m} \\
582 \mathrm{~m} \\
576 \mathrm{~m} \\
540 \mathrm{~m} \\
600 \mathrm{~m}\end{array}$ & $\begin{array}{l}\text { Garnikovo } \\
\text { Grbovec } \\
\text { Dradnja } \\
\text { Dragozel } \\
\text { Kesendre } \\
\text { Pravednik } \\
\text { Seskovo } \\
\end{array}$ & $\begin{array}{l}680 \mathrm{~m} \\
670 \mathrm{~m} \\
610 \mathrm{~m} \\
610 \mathrm{~m} \\
670 \mathrm{~m} \\
650 \mathrm{~m} \\
620 \mathrm{~m} \\
\end{array}$ & & $\begin{array}{l}720 \mathrm{~m} \\
710 \mathrm{~m} \\
740 \mathrm{~m} \\
830 \mathrm{~m} \\
820 \mathrm{~m} \\
800 \mathrm{~m}\end{array}$ & & \\
\hline Municipality P & ilep & Municipality & ivogastani & & $850 \mathrm{~m}$ & & \\
\hline Gugakovo & $580 \mathrm{~m}$ & Bela Crkva & $603 \mathrm{~m}$ & & $750 \mathrm{~m}$ & & \\
\hline Dren & $570 \mathrm{~m}$ & Vogani & $603 \mathrm{~m}$ & Municipality Pri & ilep & & \\
\hline $\begin{array}{l}\text { Klepac } \\
\text { Nikodin } \\
\text { Podmol }\end{array}$ & $\begin{array}{l}590 \mathrm{~m} \\
600 \mathrm{~m} \\
600 \mathrm{~m}\end{array}$ & $\begin{array}{l}\text { Korenica } \\
\text { Krivogastani } \\
\text { MirceAcev } \\
\end{array}$ & $\begin{array}{l}623 \mathrm{~m} \\
607 \mathrm{~m} \\
609 \mathrm{~m}\end{array}$ & $\begin{array}{l}\text { Belovodica } \\
\text { Besiste } \\
\text { Varos }\end{array}$ & $\begin{array}{l}800 \mathrm{~m} \\
900 \mathrm{~m} \\
830 \mathrm{~m}\end{array}$ & & \\
\hline Topolcani & $600 \mathrm{~m}$ & Municipality & usevo & Veprcani & $800 \mathrm{~m}$ & & \\
\hline $\begin{array}{l}\text { Trojaci } \\
\text { Trojkrsti } \\
\text { Cepigovo }\end{array}$ & $\begin{array}{l}600 \mathrm{~m} \\
600 \mathrm{~m} \\
600 \mathrm{~m}\end{array}$ & $\begin{array}{l}\text { Aldanci } \\
\text { Arilevo }\end{array}$ & $\begin{array}{l}645 \mathrm{~m} \\
660 \mathrm{~m}\end{array}$ & $\begin{array}{l}\text { Volkovo } \\
\text { Vrpsko }\end{array}$ & $\begin{array}{l}780 \mathrm{~m} \\
800 \mathrm{~m}\end{array}$ & & \\
\hline
\end{tabular}




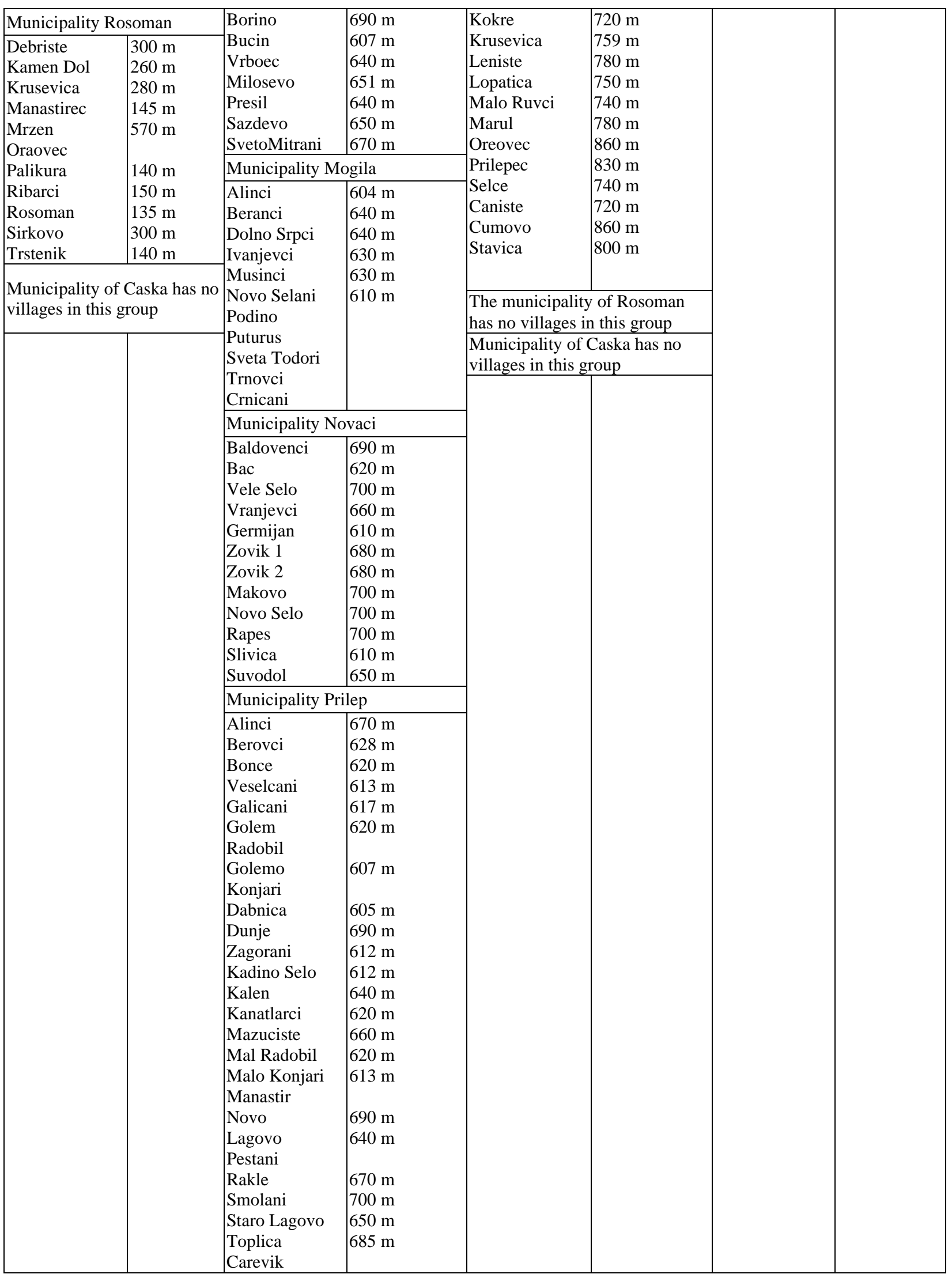




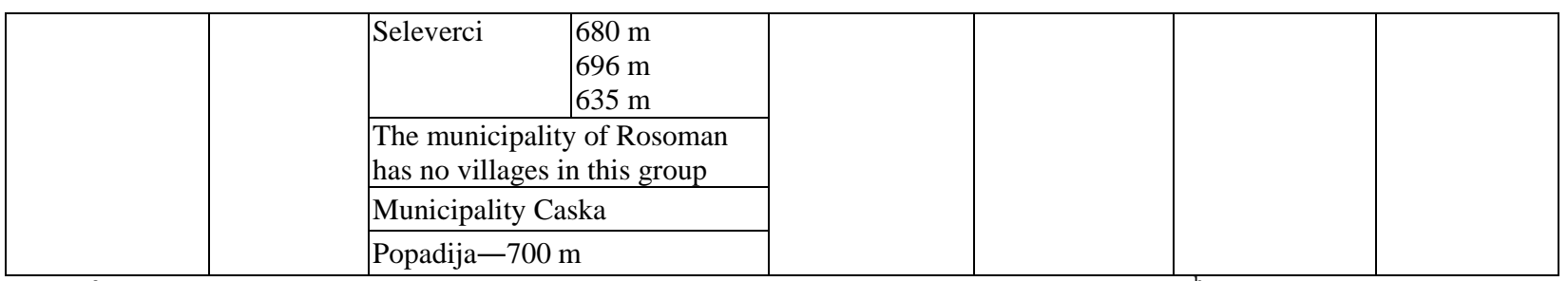

Notes. ${ }^{a}$ Panov, M. (1998). Encyclopaedia of the villages in the Republic of Macedonia, Skopje; ${ }^{b}$ Military Geographic Institute (1972). Printing maps with scale 1: 25000 (Gaus Kriger’s projection) for the territory of the Republic of Macedonia (216 sections), Belgrade.

For a clear view of the height distribution of rural settlements by municipalities and their total number of villages, especially for each category of altitude in the Crna Reka River Basin in the Republic of Macedonia, we will use the data from Table 2.

Table 2

Total Number of Villages by Municipalities According to the Categories of Altitude in the Black River Basin in the Republic of Macedonia

\begin{tabular}{|c|c|c|c|c|c|}
\hline Општина & 0-600м.н.в & 600-700м.н.в. & 700-900м.н.в. & над 900м.н.в & Total \\
\hline Bitola & 16 & 16 & 19 & 13 & 65 \\
\hline Gradsko & l & 1 & l & l & 1 \\
\hline DemirHisar & I & 17 & 14 & 10 & 40 \\
\hline Dolneni & 1 & 28 & 8 & I & 37 \\
\hline Drugovo & I & l & l & 3 & 3 \\
\hline Kavadarci & 12 & 7 & 5 & 1 & 25 \\
\hline Krivogastani & 6 & 6 & l & l & 12 \\
\hline Krusevo & l & 9 & 6 & 3 & 18 \\
\hline Mogila & 11 & 11 & 1 & I & 23 \\
\hline Novaci & 10 & 12 & 15 & 4 & 41 \\
\hline Prilep & 10 & 25 & 19 & 5 & 59 \\
\hline Rosoman & 10 & I & I & I & 10 \\
\hline Caska & / & 1 & l & / & 1 \\
\hline Total & 76 & 133 & 87 & 39 & 335 \\
\hline
\end{tabular}

Notes. ${ }^{a}$ Panov, M. (1998). Encyclopaedia of the villages in the Republic of Macedonia, Skopje; ${ }^{b}$ Military Geographic Institute (1972). Printing maps with scale 1: 25000 (Gaus Kriger’s projection) for the territory of the Republic of Macedonia (216 sections), Belgrade; ${ }^{\mathrm{C}}$ The calculations are from the author.

According to the results from Table 2, we find that the largest number of villages 133 is located at an altitude of 600-700 m, in the Crna Reka Basin in the Republic of Macedonia.

Second place is 87 villages at an altitude of 700-900 meters, in the Black River Basin in the Republic of Macedonia; In the third place, there are 76 villages at an altitude of 0-600 m, in the river basin of Crna Reka in the Republic of Macedonia; and in the fourth place, there are 39 villages at an altitude above 900 meters, in the Crna Reka River Basin in the Republic of Macedonia.

The rural settlements located in the groups with altitudes 0-600 and 600-700 meters above sea level make up 209 villages as flatland in the river Crna Reka in the Republic of Macedonia. In these villages, there are favorable conditions for the development of agriculture, especially the cultivation of cereals, tobacco production, sunflower, and viticulture. In the plain part, there are also good conditions for growing large livestock and producing milk in small family farms. The rural settlements located in the groups with an altitude 
of 700-900 and above 900 meters above sea level comprise 126 villages as a hilly mountain in the river Crna Reka in the Republic of Macedonia. In these villages, there are favorable conditions for development of horse-breeding, sheep breeding, forestry, herbalism, and development of rural tourism. The Crna Reka Basin includes part of the National Park Pelister and the village Nizhepole where there are ski lifts, hotels, and private houses for weekend tourists. In the basin of Crna Reka, it is quite interesting for the development of mountain and hunting tourism, the Mariovo region, which extends to the territory of three municipalities: Novaci, Prilep, and Kavadarci. In the Mariovo region, in the municipalities of Novaci and Prilep, there are large reserves of coal. The largest Mining Energy Combine (REK) located in the Municipality of Novaci where Thermo Power Plant works and produces more than $80 \%$ of the electricity in the Republic of Macedonia.

\section{Conclusion}

In the Crna River Basin in the Republic of Macedonia, there are 335 villages.

According to the obtained data in the group of villages with altitude of 0-600 m, there are 76 villages in the Crna Reka Basin.

In the group of villages at an altitude of 600-700 meters, in the basin of Crna Reka, there is the largest number of 133 villages.

In the group of villages with an altitude of 700-900 meters, in the basin of Crna Reka, there is a second group of 87 villages.

In the group of villages with an altitude above 900 meters, in the basin of Crna Reka, there is the smallest group of 39 villages.

We can freely conclude that in both groups of villages with an altitude of 700-900 m and over $900 \mathrm{~m}$, there are good conditions for the development of rural tourism in the Black River Basin in the Republic of Macedonia. 


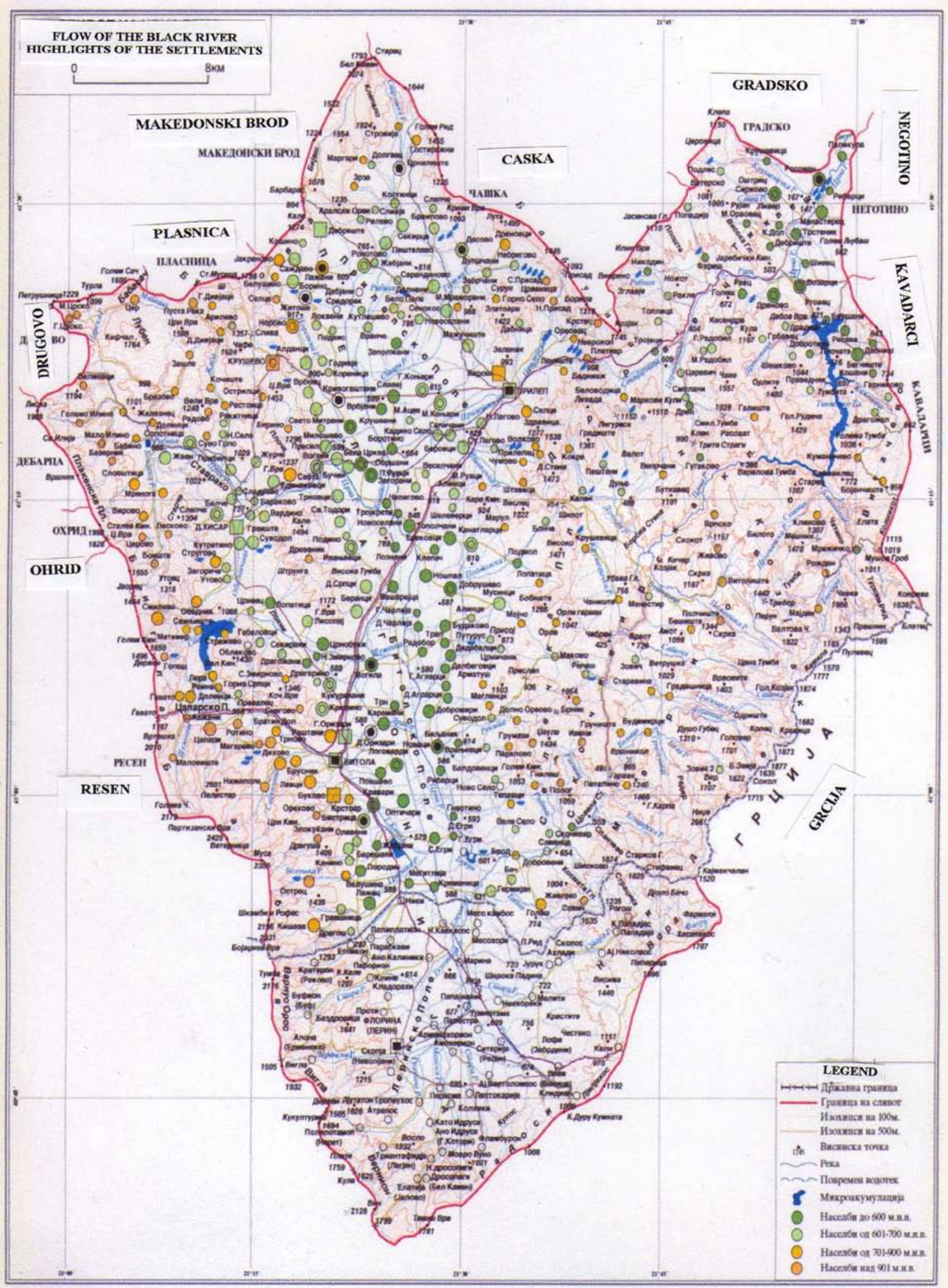

Figure 1. Figure of the Black River Basin in the Republic of Macedonia and the height distribution of the settlements. 


\section{References}

Dimitrov, V. N., \& Koteski, C. (2015). Tourist geography—textbook. Stip: University GoceDelčev (UGD). (in Macedonia)

DNU (1987). Mariovo, natural and socio-economic features and development opportunities. Prilep: Printing house, 11 OktomvriPrilep (in Macedonia)

Koteski, C. (2004). The thematic atlas of Mariovo and Raecka valley (Master's thesis in manuscript, Institute of Geography, University St. Cyril and Methodius, Skopje). (in Macedonia)

Koteski, C. (2009). PlumnaCrnaReka-Geographic cartographic modeling, differentiation and functional development of certain regional entities (Doctoral dissertation in the manuscript, Institute of Geography, University St. Cyril and Methodius, Skopje). (in Macedonia)

Koteski, C. (2011). Plum of Crna Reka. Shtip: Printing house 2 August. (in Macedonia)

Panov, M. (1984). Social geography (Settlements). Skopje: University printing house - Skopje. (in Macedonia)

Panov, M. (1998). Encyclopedia of the villages in R. Macedonia. Tetovo: Printing company Joint Stock Company “Napredok” -Tetovo. (in Macedonia)

Republic Institute for Statistics (2002). Census of Population in 2002. Skopje, Macedonia: State Census of Population and Households in the Republic of Macedonia in 2002. 